TITLE:

Signaling via toll-like receptor 4 and CD40 in B cells plays a regulatory role in the pathogenesis of multiple sclerosis through interleukin-10 production(Abstract_要旨)

\title{
AUTHOR(S):
}

\section{Okada, Yoichiro}

\section{CITATION:}

Okada, Yoichiro. Signaling via toll-like receptor 4 and CD 40 in B cells plays a regulatory role in the pathogenesis of multiple sclerosis through interleukin-10 production. 京都大学, 2018, 博士(医学)

ISSUE DATE:

2018-03-26

URL:

https://doi.org/10.14989/doctor.k21017

RIGHT: 


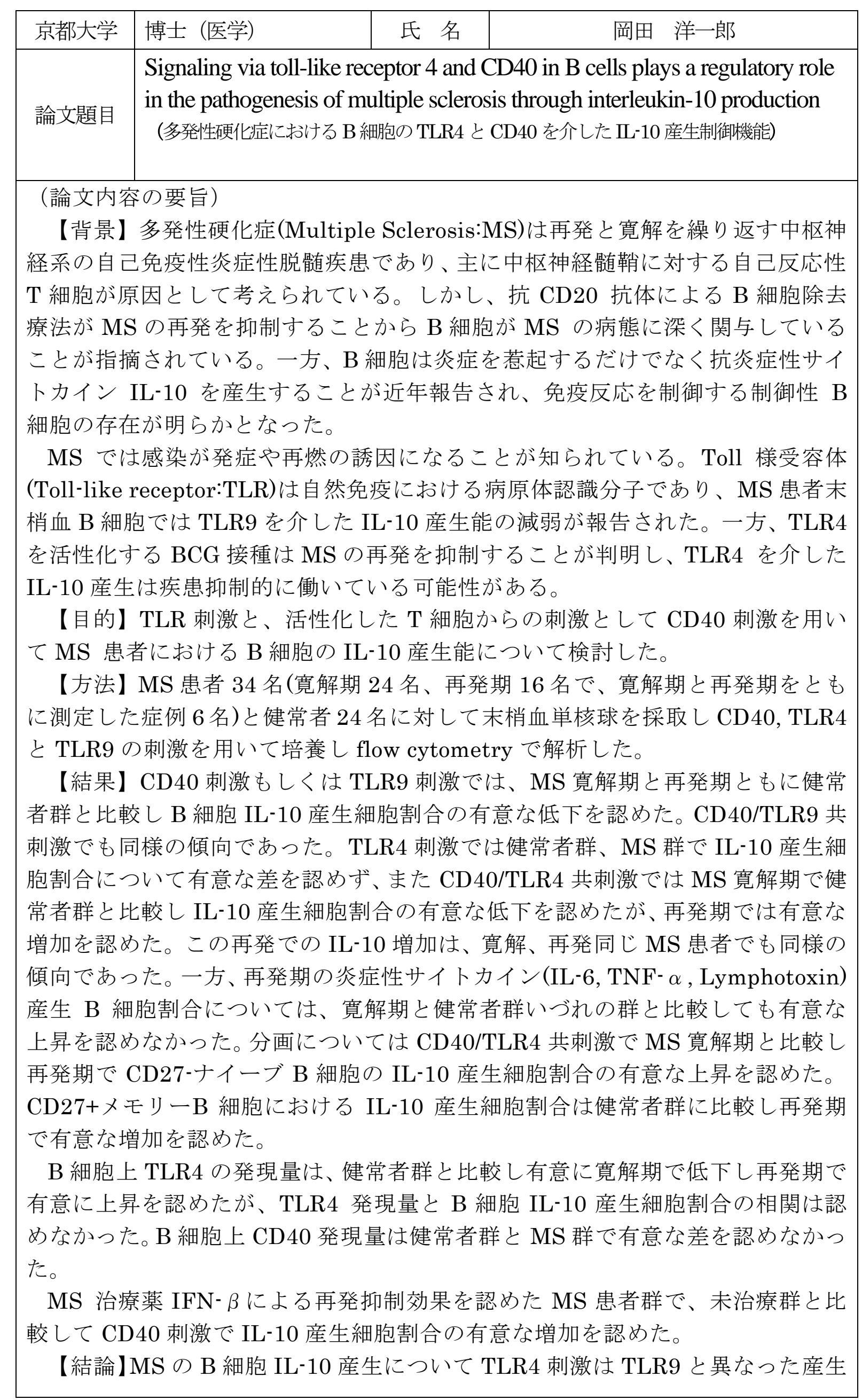

パターンを示し、TLR4 に CD40 刺激を加えた再発時 B 細胞は IL-10 産生能が回 復し、再発からの寛解誘導に関与する可能性が示唆された。また、IFN- $\beta$ は CD40 刺激による B 細胞の IL-10 産生を増加させ再発を抑制している可能性が示唆さ れた。

\section{(論文審査の結果の要旨)}

多発性硬化症(Multiple Sclerosis: MS)は時間的、空間的に再発と寛解を繰り返す中枢神経 系の自己免疫性炎症性疾患で B 細胞がその病態に関与することが知られているが、 $\mathrm{B}$ 細胞 のIL-10 産生による制御機能については未解明の部分が多い。

本研究では、ヒト末梢血単核球に Toll 様受容体4(Toll-like receptor 4:TLR4)または TLR9 刺激を加えて培養後 B 細胞 IL-10 産生能を検討した。TLR9 では、MS 患者では健常者と 比較し IL-10 産生能が低下していることを明らかにした。TLR4 刺激では TLR9 と異なり、 MS 患者では健常者と変わらず IL-10 産生能が保たれていた。さらに、TLR4に CD40 刺激 を加えると B 細胞 IL-10 産生能が寛解期と比較し再発期に上昇していることが明らかとな った。CD40 と TLR4 の共刺激系において IL-10 産生 B 細胞は、CD27-naïve B 細胞から主 に産生されていることを確認した。また、MS 治療薬 IFN- $\beta$ によって再発が抑制されてい る治療反応性のよい MS 患者では、CD40 刺激による B 細胞 IL-10 産生が無治療の MS 患 者と比較し上昇していることを明らかにした。

以上の研究は CD40 と TLR4 を介した IL-10 産生 B 細胞制御機能の解明に貢献し、多発 性硬化症の病態解析に寄与するところが多い。

したがって、本論文は博士（医学 ）の学位論文として価值あるものと認める。

なお、本学位授与申請者は、平成 30 年 2 月 15 日実施の論文内容とそれに関 連した試問を受け、合格と認められたものである。 